\title{
Diagnostic and prognostic characteristics of phytotoxicity caused by fluoride on Spondias dulcis Forst. F. (Anacardiaceae)
}

\author{
BRUNO F. SANT'ANNA-SANTOS ${ }^{1}$, ARISTÉA A. AZEVEDO ${ }^{2}$, LUZIMAR C. SILVA ${ }^{2}$ and MARCO A. OLIVA ${ }^{2}$ \\ ${ }^{1}$ Universidade Federal de Minas Gerais, Campus Regional Montes Claros, \\ Av. Universitária, 1000, Caixa Postal 135, Bairro Universitário, 39404-547 Montes Claros, MG, Brasil \\ ${ }^{2}$ Universidade Federal de Viçosa, Departamento de Biologia Vegetal, \\ Av. PH Rolfs, s/n, Centro, 36570-000 Viçosa, MG, Brasil
}

Manuscript received on August 23, 2010; accepted for publication on November 16, 2010

\begin{abstract}
The goal of this study was to determine the symptoms and microscopic damage caused by fluoride on Spondias dulcis, a fluoride-sensitive species. The plants were exposed to simulated fog with fluoride $\left(0,5,10,15\right.$ and $\left.20 \mathrm{mg} \mathrm{L}^{-1}\right)$ for 20 min daily during four consecutive days. Samples from leaflets without any apparent fluoride injury were collected to microscopic analysis. The percentage of necrosed leaf area was measured, and the level of pollutant in the dry matter from the basal and apical portions of the plant was determined. The necroses began $24 \mathrm{~h}$ after the first simulation mainly from the base of the leaflets. A higher level of necrosis was observed at the apical portion of the plants, a region of higher fluoride accumulation. The damage on the surface of the leaflets was characterized as plasmolysis, erosion of the epicuticular waxes and epidermal rupture. Structurally, the noticeable accumulation of granules and droplets green stained by toluidine blue in the spongy parenchima and the boundaries of ending veinlets was observed. The limb thickness reduction occurred due to plasmolysis in the mesophyll, showing an apparent correlation with the damage observed on the surface. The parameters observed in the laboratory are promising for field biomonitoring studies.
\end{abstract}

Key words: Leaf anatomy, bioindicator, necrosis, pollution, symptomatology.

\section{INTRODUCTION}

Fluoride, an extremely phytotoxic atmospheric pollutant (Smith and Hodge 1979), can be released into the atmosphere during the production of aluminium, bricks, glass, and steel (Fornasiero 2001). In Brazil there is little data regarding the concentration of fluoride in the atmosphere, most of them restricted to Cubatão city, São Paulo

Correspondence to: Bruno F. Sant'Anna-Santos

E-mail: brunoufmg@ufmg.br
State (Klumpp et al. 1996a, b, 1998, Domingos et al. 2003). However, the aluminium industry has been blamed for the emission of this pollutant, for instance, at the metallurgical zone in Minas Gerais State (Divan Junior et al. 2007, 2008).

Some plant species, such as Panicum maximum cv. Colonião and Chloris gayana, have been used in Brazil as bioindicators for detecting the presence of fluoride in the atmosphere (Divan Junior et al. 2007). When carrying out field studies, it is essential to have a prior knowledge on plant- 
specific morphoanatomical, physiological and biochemical responses to fluoride. Information from prior experiments in laboratory makes it possible to precisely diagnose plant injuries (Silva et al. 2000, Fornasiero 2001, Chaves et al. 2002, Oliva and Figueiredo 2005).

The symptomatology, the most used parameter for assessing the sensitivity of a plant species to several stress factors, frequently requires additional validation using microscopy (Vollenweider et al. 2003, Reig-Arminaña et al. 2004). Non-specific symptoms such as chlorosis and necrosis, in addition to not being useful in determining the nature of the stressing agent involved (Günthardt-Goerg and Vollenweider 2007), also elicit statements such as the following: "all environmental stresses lead to chlorophyll degradation" (Munné-Bosch and Alegre 2004) or "if no pathogen is found, an abiotic cause for the disease must be considered". However, according to Günthardt-Goerg and Vollenweider (2007), if supported by microscopy, the symptomatology may be used in the precise diagnosis of stress. The macroscopic and microscopic studies, in most cases, must therefore be integrated to assure an accurate diagnosis.

The symptomatology and the microscopic characterization of the injury have been used as biomarkers in several studies aimed at determining the sensitivity of a species to fluoride (Silva et al. 2000, Fornasiero 2001, Chaves et al. 2002, Oliva and Figueiredo 2005, Peixoto et al. 2005). However, there has been little focus on the prognostic value of microscopic parameters.

In several countries, a standardized method has been employed to monitor areas polluted with fluoride (VDI 1982). This method uses Lolium multiflorum ssp. italicum, a grass species that accumulates fluoride (Ruthsatz and Wey 1991). However, Ellenberg (1991) questioned the universal use of this species, since changes in the ecophysiological properties of $L$. multiflorum can mask the fluoride-specific symptomatology. The scarcity of data addressing the sensitivity of this tropical species to pollution limits the possible biomonitoring programs and the assessment of the environmental impacts, reinforcing the need for more studies concerning this species (Silva et al. 2000).

Spondias dulcis Forst. F. (Anacardiaceae), commonly known as cajá-mirim, is a perennial species from Polynesia that is distributed throughout Brazil (Souza et al. 1998), mainly in south and southeast of the country (Lorenzi et al. 2003). $S$. dulcis, has pinnately compound leaves with 7-11 pairs of membranaceous leaflets ranges from 10 to $15 \mathrm{~mm}$ in height (Lorenzi et al. 2003). Due to its high sensitivity to fluoride in comparison to other tropical tree species, Silva et al. (2000) highlighted the potential use of $S$. dulcis as a bioindicator and proposed depth studies to precisely diagnose the injuries caused by fluoride. The aim of this study is to determine the damage caused by fluoride on the leaf blades of $S$. dulcis under laboratory conditions.

\section{MATERIALS AND METHODS}

S. dulcis, a tropical tree species sensitive to fluoride (Silva et al. 2000), was supplied by the Nursery of Parque Estadual do Rio Doce-MG (NPERD). The plants were obtained from seminiferous propagation from a unique adult individual located at an altitude of $280 \mathrm{~m}$, at the coordinates Lat $19^{\circ} 57^{\prime} 04^{\prime \prime} \mathrm{S}$ and Long $42^{\circ} 50$ '27' W, mapped through the global positioning system (GPSII plus, Garmin Ltd., Hampshire, UK) at the boundaries of NPERD. The voucher specimen was stored at VIC Herbarium under the number 29607.

Sowing was performed in plastic bags that were $100 \mathrm{~mm}$ in diameter and $220 \mathrm{~mm}$ in length, and containing soil from NPERD (Tab. I). Two months after sowing the plants were transferred to a greenhouse for acclimation. The greenhouse was located at Department of Plant Biology, Federal University of Viçosa, at an altitude of $649 \mathrm{~m}$ and at the coordinates Lat $20^{\circ} 45^{\prime} 20^{\prime \prime} \mathrm{S}$ and Long $42^{\circ} 52^{\prime} 40^{\prime \prime} \mathrm{W}$. After being transferred to $2.6 \mathrm{dm}^{3}$ pots, the plants received Hoagland 0.25-strength 
TABLE I

Results from the chemical analysis of the soil used as a substrate in the pots.

Abbreviations: SB: Sum of exchangeable bases; CTC (t): Effective cation capacity exchangeable; CTC (T): Cation to capacity exchangeable pH 7.0; V: Index of base saturation; M: Index of Aluminum saturation; ISNa: Index of Sodium saturation; SOM (soil organic matter) = C x 1.724 - Walkley Black method; P-rem: Remaining Phosphorus.

\begin{tabular}{ccccccccccc}
\hline $\mathbf{p H}$ & $\mathbf{P}$ & $\mathbf{K}$ & $\mathbf{N a}$ & $\mathbf{C a}^{2+}$ & $\mathbf{M g}^{2+}$ & $\mathbf{A l}^{\mathbf{3}}$ & $\mathbf{H}+\mathbf{A l}$ & $\mathbf{S B}$ & $\mathbf{C T C}(\mathbf{t})$ & $\mathbf{C T C}$ (T) \\
\hline $\mathrm{H}_{2} \mathrm{O}$ & & $\mathrm{mg} \mathrm{dm}{ }^{-3}$ & & & & & $\mathrm{cmol}_{\mathrm{c}} \mathrm{dm}^{-3}$ & & & \\
\hline 7.25 & 19.1 & 1727 & - & 6.16 & 1.12 & 0.0 & 1.0 & 11.7 & 11.7 & 11.7 \\
\hline $\mathbf{V}$ & $\mathbf{m}$ & $\mathbf{I S N a}$ & $\mathbf{S O M}$ & $\mathbf{P}-\mathbf{r e m}$ & $\mathbf{Z n}$ & $\mathbf{F e}$ & $\mathbf{M n}$ & $\mathbf{C u}$ & $\mathbf{B}$ & $\mathbf{S}$ \\
\hline & $\%$ & & $\mathrm{dag} \mathrm{kg}{ }^{-1}$ & $\mathrm{mg} \mathrm{L}-1$ & & & & $\mathrm{mg} \mathrm{dm}^{-3}$ & & \\
\hline 92.1 & 0 & - & 3.68 & 23.3 & - & 21.6 & 54.1 & 0.48 & 6.84 & 262.6 \\
\hline
\end{tabular}

nutritive solution (Hoagland and Arnon 1950) at every five days during the acclimation period (two months) and until the end of the experiment.

The simulation experiment was adapted from the method proposed by Silva et al. (2000). S. dulcis plants average $380 \mathrm{~mm}$ in height and have an average of 8 knots presenting compound leaves with seven leaflets. The plants were exposed daily for $20 \mathrm{~min}$, totalling $5.22 \mathrm{~mm}$ day $^{-1}$ of precipitation, in a simulation chamber with a spray system adapted from the model proposed by Evans et al. (1977). Treatments were applied in a completely randomized design with five treatments $(0,5,10$, 15 and $20 \mathrm{mg} \mathrm{L}^{-1}$ ) and five plants per treatment. The treatments with fluoride $(\mathrm{pH}=6.0)$ were prepared by adding potassium fluoride to deionised water. The fog applied in the control treatment contained only deionised water at $\mathrm{pH}$ 6.0. Before and after each fog, the plants were placed under a luminous panel for 15 min, under an irradiance of $95 \mathrm{~W} \mathrm{~m}^{-2}$ provided by eight incandescent high-pressure mercury lamps (E$27,220-230 \mathrm{~V}, 250 \mathrm{~W})$. The plants remained under ambient light conditions $\left(24.8 / 17.5 / 11.9^{\circ} \mathrm{C}\right.$ average of the maximum/middle/low temperatures, relative humidity $83.6 \%$ ) the rest of the time. The beginning of leaf abscission in the plants exposed to fluoride (after the fourth fog) determined the end of the experiment.

During the simulation period all leaflets of plants in the five different treatments were photographed daily with the aim of recording the beginning of symptoms and the evolution of the necroses caused by the pollutant. The photographs were taken using a digital camera. At the end of the experiment, all leaves from the basal portion ( $5^{\text {th }}$ knot from the apical bud to the $8^{\text {th }} \mathrm{knot}$ ) and apical portion $\left(1^{\text {st }}\right.$ knot from the apical bud to the $4^{\text {th }}$ knot) of each S. dulcis plant were digitalized and analyzed using Image Pro-Plus, version 4.1 for Windows ${ }^{\circledR}$ (Media Cybernetics, Silver Spring, MD, USA) to calculate the percentage of necrosed leaf area.

All leaves $(n=5)$ from the basal and apical portion of plants from all treatments were dried in a stove at $70{ }^{\circ} \mathrm{C}$ and reduced to particles with dimensions of less than $1 \mathrm{~mm}$ using a Wiley grinder. Then, $0.5 \mathrm{~g}$ aliquots of each sample were extracted in $0.1 \mathrm{M}$ perchloric acid (Garcia-Ciudad et al. 1985) using an ionic strength adjustment buffer (Larsen and Widdowson 1971) for the potentiometric determination of the fluoride content. The analyses were carried out in duplicate and repeated twice.

Only the leaflets without any apparent fluoride injury were collected to microscopic analysis. Samples were collected from leaves from the $3^{\text {rd }}$ or $4^{\text {th }}$ knots (from the apical bud) at the end of the experiment. The samples were collected from the middle portion of one representative leaflet of each plant $(n=5)$ and fixed in Karnovsky's solution (glutaraldehyde 
solution (2.5\%) and paraformaldehyde (4\%), with sodium cacodylate buffering - $\mathrm{pH} 7.2$ - and the addition of calcium chloride $5 \mathrm{mM}$ (Karnovsky 1965).

For the scanning electron microscopy analysis, the samples fixed in Karnovsky's solution were post-fixed in osmium tetroxide $(1 \%)$, dehydrated in ethylic series and dried until the critical point (model CPD 020, Bal-Tec, Balzers, Liechtenstein). The leaflets were covered with gold using the cathodic spray process in a Sputter Coater (model FDU010, Bal-Tec, Balzers, Liechtenstein). The analyses were made using SEM LEO 1430 VP, Zeiss (Cambridge, England).

With regard to the anatomical studies, after fixation in Karnosvsky's solution and dehydration in the ethylic series, the samples were placed in methacrylate (Historesin, Leica Instruments, Heidelberg, Germany). Transversal and paradermal sections ( 8 and $3 \mu \mathrm{m}$ thick, respectively) were obtained using a rotary microtome (model RM2155, Leica Microsystems Inc., Deerfield, USA) and stained with toluidine blue $(\mathrm{pH}=4.0) \quad\left(\mathrm{O}^{\prime}\right.$ Brien and McCully 1981), and the slides were mounted in Permount. The images were obtained using a light microscope with a digital camera (model Olympus AX70TRF, Olympus Optical, Tokyo, Japan).

For the micromorphometric evaluations we measured the percentage of intercellular spaces in the spongy parenchyma in the paradermal sections. In the transversal sections we measured the thickness of the limb, palisade parenchyma and spongy parenchyma, and the height of the adaxial and abaxial epidermis at the leaf mid-region. We performed 27 measures/repetitions/parameters totalling 162 records per repetition. The Image ProPlus, version 4.1 for Windows ${ }^{\circledR}$ (Media Cybernetics, Silver Spring, MD, USA) was used.

The experimental delineation was completely randomized with five treatments $(0,5,10,15$, and $20 \mathrm{mg} \mathrm{L}^{-1}$ ) and five plants per treatment. The data were submitted to analysis of variance (ANOVA) employing SAEG software (Euclydes 1983), and the measurements from the treatments were compared using Tukey's test at $5 \%$ probability.

\section{RESULTS}

In the control treatment the leaflets of $S$. dulcis showed a uniform color (Fig. 1A), typically brilliant green without injuries. In the leaflets of plants exposed to 10,15 and $20 \mathrm{mg} \mathrm{L}^{-1}$ fluoride fog (Fig. 1B-E and 2A-F), the symptoms occurred $24 \mathrm{~h}$ after the first fluoride fog simulation. There were noticeably more severe necroses on plants subjected to fog at concentrations of 15 (Fig. 2AC) and $20 \mathrm{mg} \mathrm{L}^{-1}$ (Fig. 2D-F). Necrosis was not observed in plants exposed to $5 \mathrm{mg} \mathrm{L}^{-1}$ until after the end of the experiment. The leaf abscission began $96 \mathrm{~h}$ after the first fluoride simulated fog at concentrations of 15 and $20 \mathrm{mg} \mathrm{L}^{-1}$.

In the plants exposed to fluoride, necrosis occurred in all leaflets in marginal areas, as well as in interveinal areas, mainly at the base of the leaflets (92.5\% of the leaflets showed necrosis) (Fig. 1BE). Necrosis was characterized by the presence of three distinct color zones: blackened, greyish and brown (Fig. 1D and E).

The apical portion $\left(1^{\text {st }}\right.$ knot from the apical bud to the $4^{\text {th }}$ knot) of the plants exposed to the pollutant showed a higher percentage of necrosed leaf areas than the basal portion ( $5^{\text {th }}$ knot from the apical bud to the $8^{\text {th }}$ knot). In the leaflets from the apical portion of the plants exposed to $20 \mathrm{mg} \mathrm{L}^{-1}, 45 \%$ of the leaf area showed necrosis, while only $6 \%$ of the leaf area of leaflets from the basal portion presented injuries at the end of the experiment (Fig. 3).

The leaflets from the basal portion of the plants exposed to 5, 10, 15 and $20 \mathrm{mg} \mathrm{L}^{-1}$ fluoride showed 28.7, 51.1, 75.4 and 182.7\%, respectively, more fluoride content than the control (Fig. 4). At the basal portion of the plants, the pollutant contents were $46.6,72.5,106.5$ and $219.4 \%$, respectively. This was higher than in the control treatment (Fig. 4). 


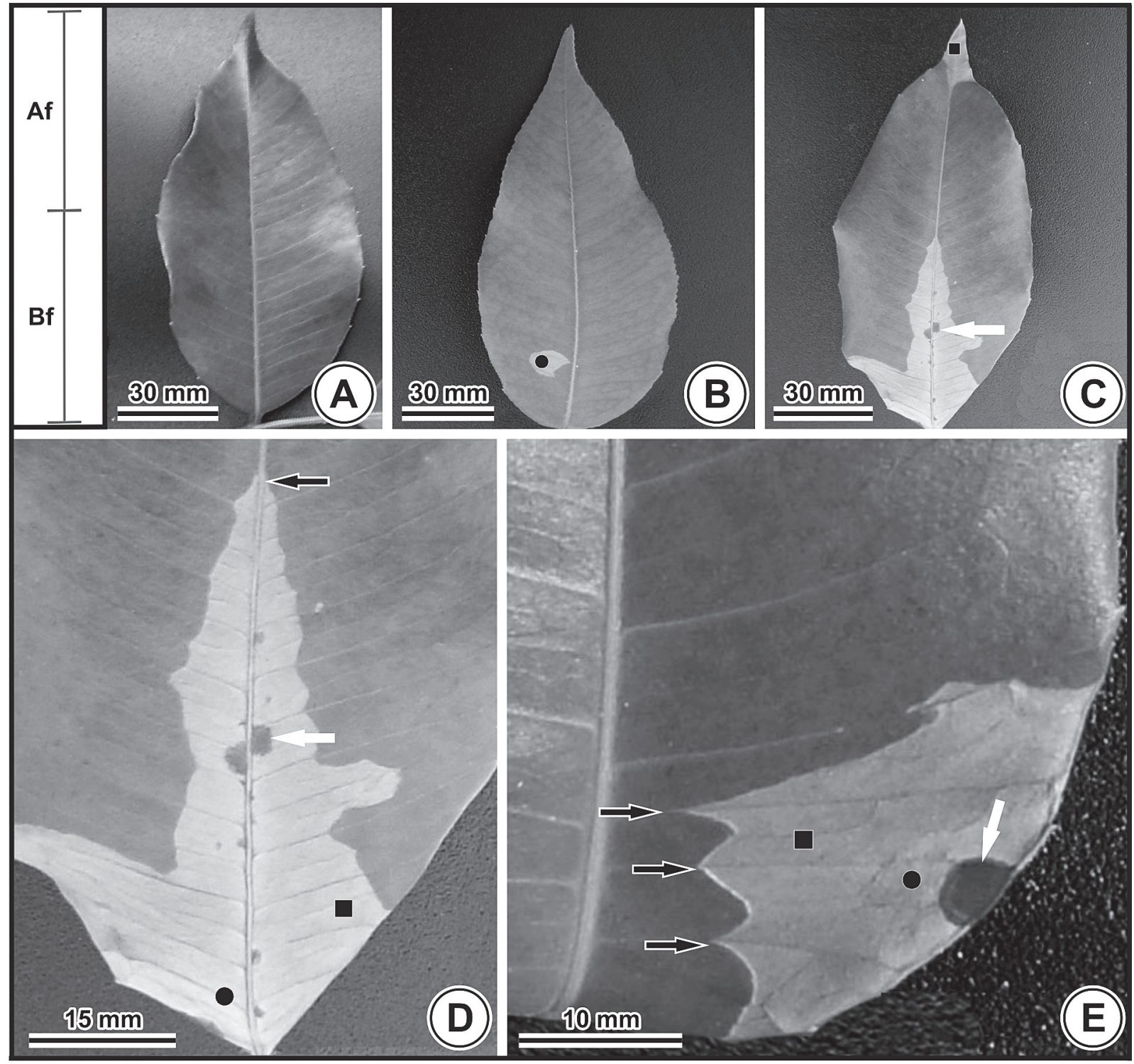

Fig. 1 - Symptoms observed in leaflets of $S$. dulcis exposed to fluoride simulated fog $\left(10 \mathrm{mg} \mathrm{L}^{-1}\right)$ during four consecutive days. (A) Control $\left(0 \mathrm{mg} \mathrm{L}^{-1}\right)$. (B-E) Fluoride treatment: necrosis consisting of three color zones - darkened (white arrow), greyish (circle) and brown (square). (B) Interveinal necrosis at the base of the leaflet (Bf). (C) Apex (Af) and base (Bf) of the leaflet that has undergone necrosis. (D) Detail of C: necrosis passing through the midrib (black arrow). (E) Necrosis passing through the lateral veins (black arrow). 


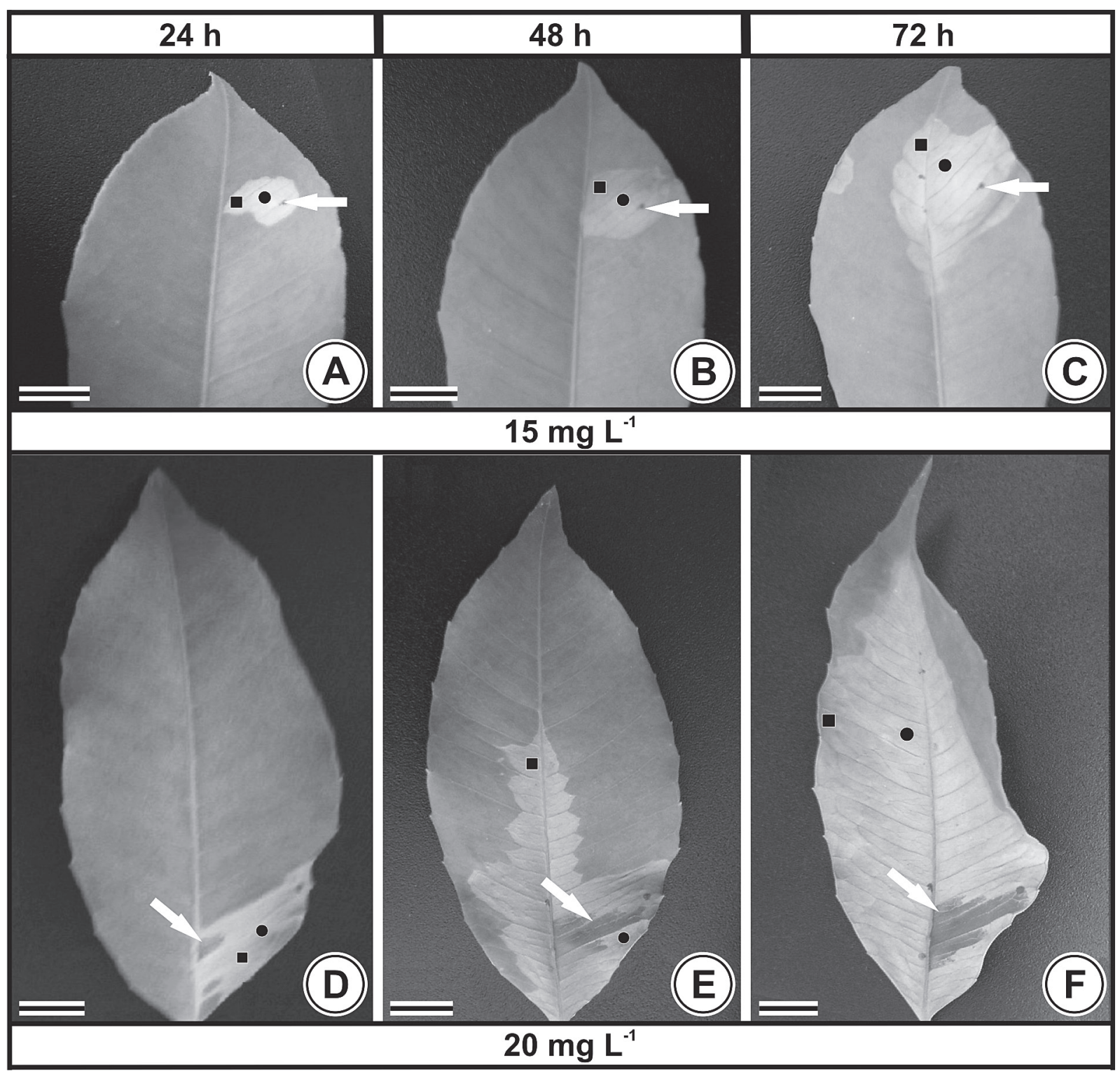

Fig. 2 - Evolution of the symptoms observed in the leaflets of S. dulcis exposed to fluoride $24 \mathrm{~h}$ (A and D), $48 \mathrm{~h}$ (B and E) and $72 \mathrm{~h}$ (C and F) after the first fog. (A-C) $15 \mathrm{mg} \mathrm{L}^{-1}$. (D-F) $20 \mathrm{mg} \mathrm{L}^{-1}$. Necrosis consisting of three color zones - darkened (white arrow), greyish (circle) and brown (square). Bars: $15 \mathrm{~mm}$. 


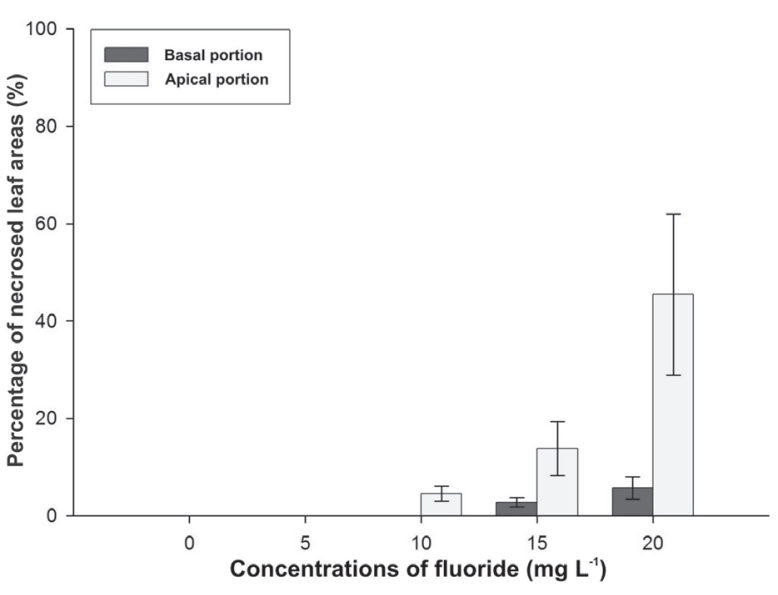

Fig. 3 - Percentage of necrosed leaf areas from the basal and apical portions of S. dulcis plants exposed to different concentrations of fluoride in simulated fog $\left(0,5,10,15\right.$ and $\left.20 \mathrm{mg} \mathrm{L}^{-1}\right)$ during four consecutive days. The vertical bars indicate the standard deviation $(n=5)$.

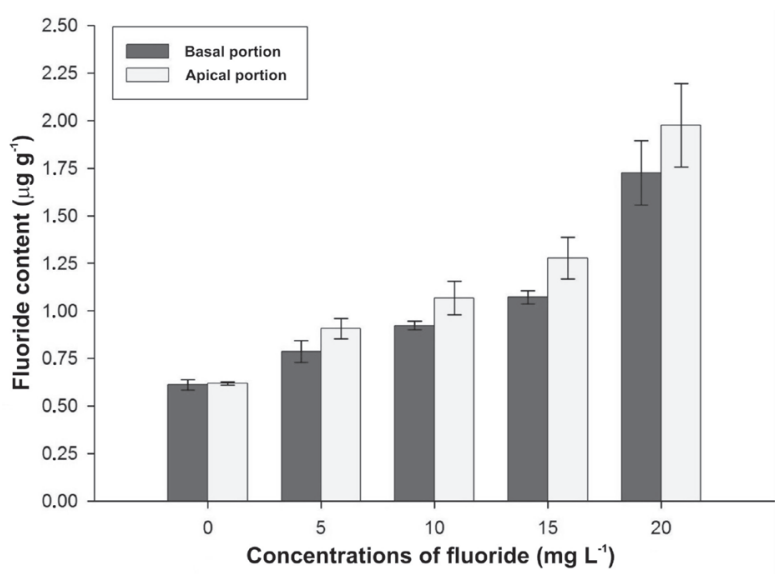

Fig. 4 - Fluoride content in leaves from the basal and apical portions of S. dulcis exposed to different concentrations of fluoride $(0,5,10,15$ and $\left.20 \mathrm{mg} \mathrm{L}^{-1}\right)$ in simulated fog during four consecutive days. The vertical bars indicate the standard deviation $(\mathrm{n}=5)$.

The correlation between the degree of leaf injury and the fluoride content in the leaves was significant $(p<0.01)$ and high on both the basal and apical portions of the plants ( 0.86 and 0.88 , respectively).

The leaflets of S. dulcis are glabrous (Fig. 5A; 6AB; 7A-B) and hypostomatic (Fig. 5A and 6A), with a unisseriate epidermis where the cells show a welldefined shape in the adaxial and abaxial faces. One layer of compact cells forms the palisade parenchima (Fig. 7A-B), while four to six layers of armed cells form the spongy parenchima (Fig. 7A and E).
All fluoride treatments caused micromorphological damage to both the adaxial and abaxial epidermis (Fig. 5 and 6). The adaxial epidermis presented turgor loss and flattening of the outer periclinal wall (Fig. 5B), showed changes in the relief of the cell groups (Fig. 5C) and demonstrated the formation of concavities in some regions of the leaf blade (Fig. 5D). Besides the relief alteration, which gives the abaxial epidermis an irregular aspect (Fig. 6B), epicuticular wax erosion areas (Fig. 6C) and the presence of fungal hyphae were observed (Fig. 6D and E). The rupture of some epidermal regions exposed the inner tissues to the pollutant (Fig. 6D and F).

All concentrations of fluoride $(5,10,15$ and $20 \mathrm{mg} \mathrm{L}^{-1}$ ) led to a significant effect on the quantitative parameters assessed in the leaflets without any apparent fluoride injury, except on the height of abaxial epidermal cells (Tab. II). The plants exposed to $20 \mathrm{mg} \mathrm{L}^{-1}$ showed a decrease of $13.3 \%$ in the thickness of the limb (Tab. II and Fig. 7B). The mesophyll and the epidermis represent 85 and $15 \%$, respectively, of the total thickness of the leaflet of S. dulcis in the control, and 83 and $17 \%$ in the plants exposed to $20 \mathrm{mg} \mathrm{L}^{-1}$. The correlation between the thickness of the limb and the height of the cells of the palisade and spongy parenchyma was high (0.86 and 0.89, respectively) and significant $(p<0.01)$. However, a significant alteration in the proportion of the palisade to spongy parenchyma was not observed. In the plants exposed to $20 \mathrm{mg} \mathrm{L}^{-1}$ there was a noticeable increase in the size of the chloroplasts (Fig. 7C-D).

The plants exposed to 10,15 and $20 \mathrm{mg} \mathrm{L}^{-1}$ showed a significant increase $(p<0.05)$ in the percentage of intercellular spaces in comparison with the control (Tab. II). They also had an accumulation of granules that were strongly stained (green) by toluidine blue (Fig. 7B and F) and droplets surrounding the ending veinlets (Fig. $7 \mathrm{G})$ at the interface between the palisade and the spongy parenchyma. 


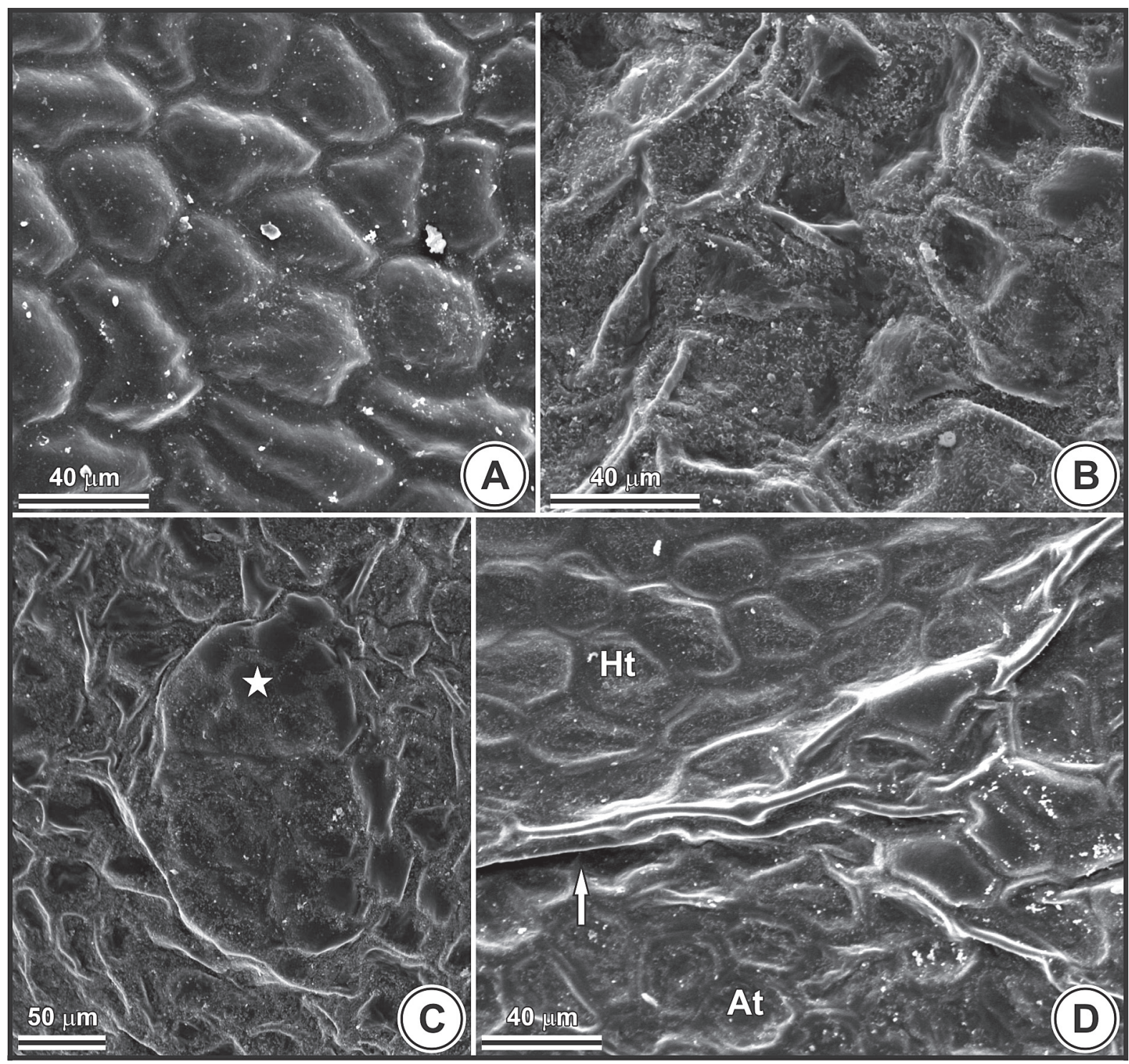

Fig. 5 - Adaxial epidermis of $S$. dulcis (scanning electron micrographs). (A) Control treatment. (B-D) Fluoride. (A) Turgid cells. (B) 5 mg L ${ }^{-1}$ : details of cells with flat outer walls. (C) $10 \mathrm{mg} \mathrm{L}^{-1}$ : star shows an alteration in the cell relief. (D) $20 \mathrm{mg} \mathrm{L}^{-1}$ : arrow shows concavities at the interface between affected and healthy tissues. Abbreviations: At: affected tissue; Ht: healthy tissue. 


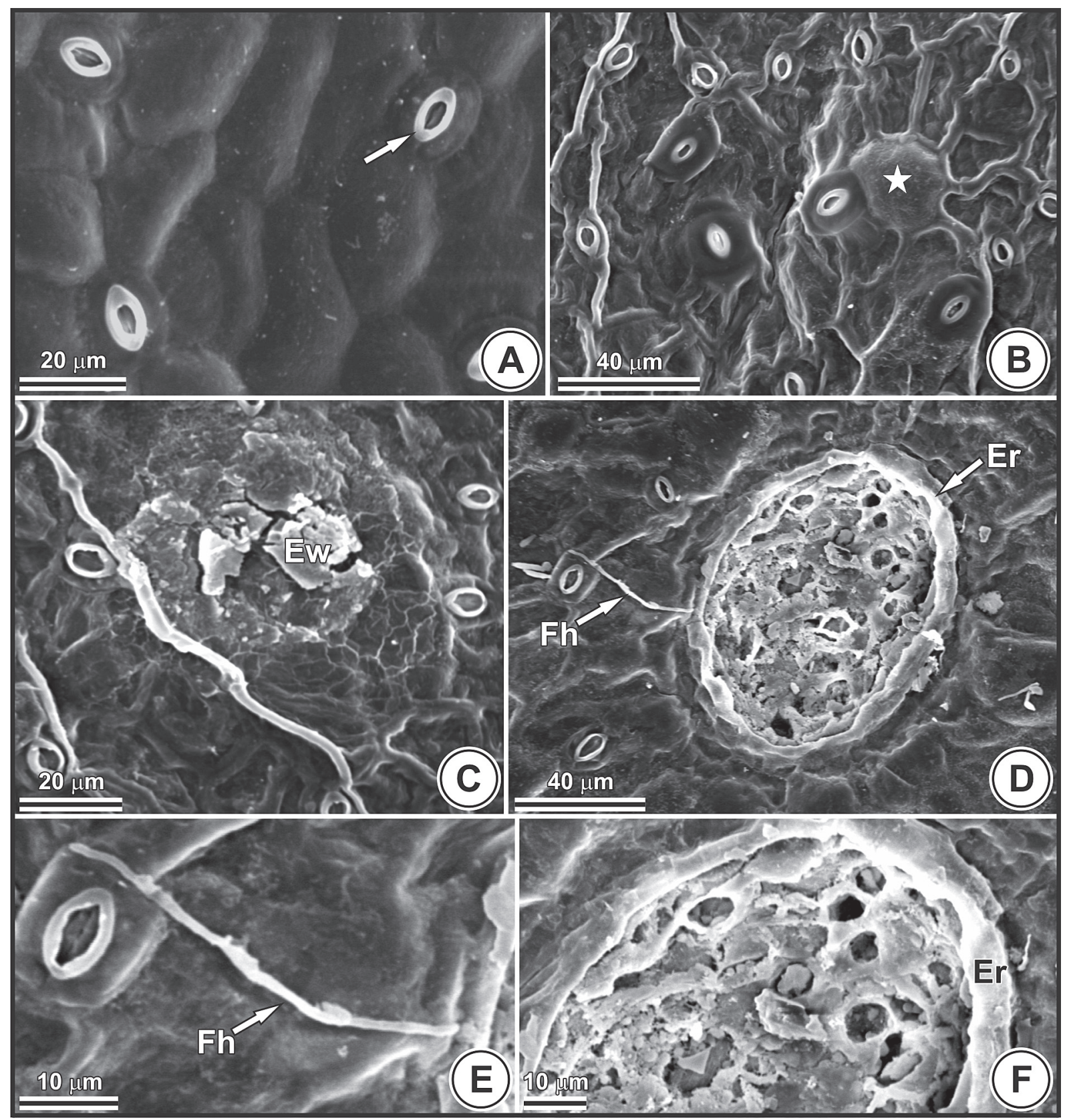

Fig. 6 - Abaxial epidermis of $S$. dulcis (scanning electron micrographs). (A) Control treatment. (B-F) Fluoride. (A) Arrow indicates stomata. (B) $10 \mathrm{mg} \mathrm{L}^{-1}$ : star indicates the area with altered cell shape. (C) $15 \mathrm{mg} \mathrm{L}^{-1}$ : epicuticular wax erosion. (D) $20 \mathrm{mg} \mathrm{L}^{-1}$ : Region with epidermis rupture and fungal hyphae. (E and F) Detail of D. Abbreviations: Ew: epicuticular wax; Er: epidermal rupture; Fh: fungi hyhae. 


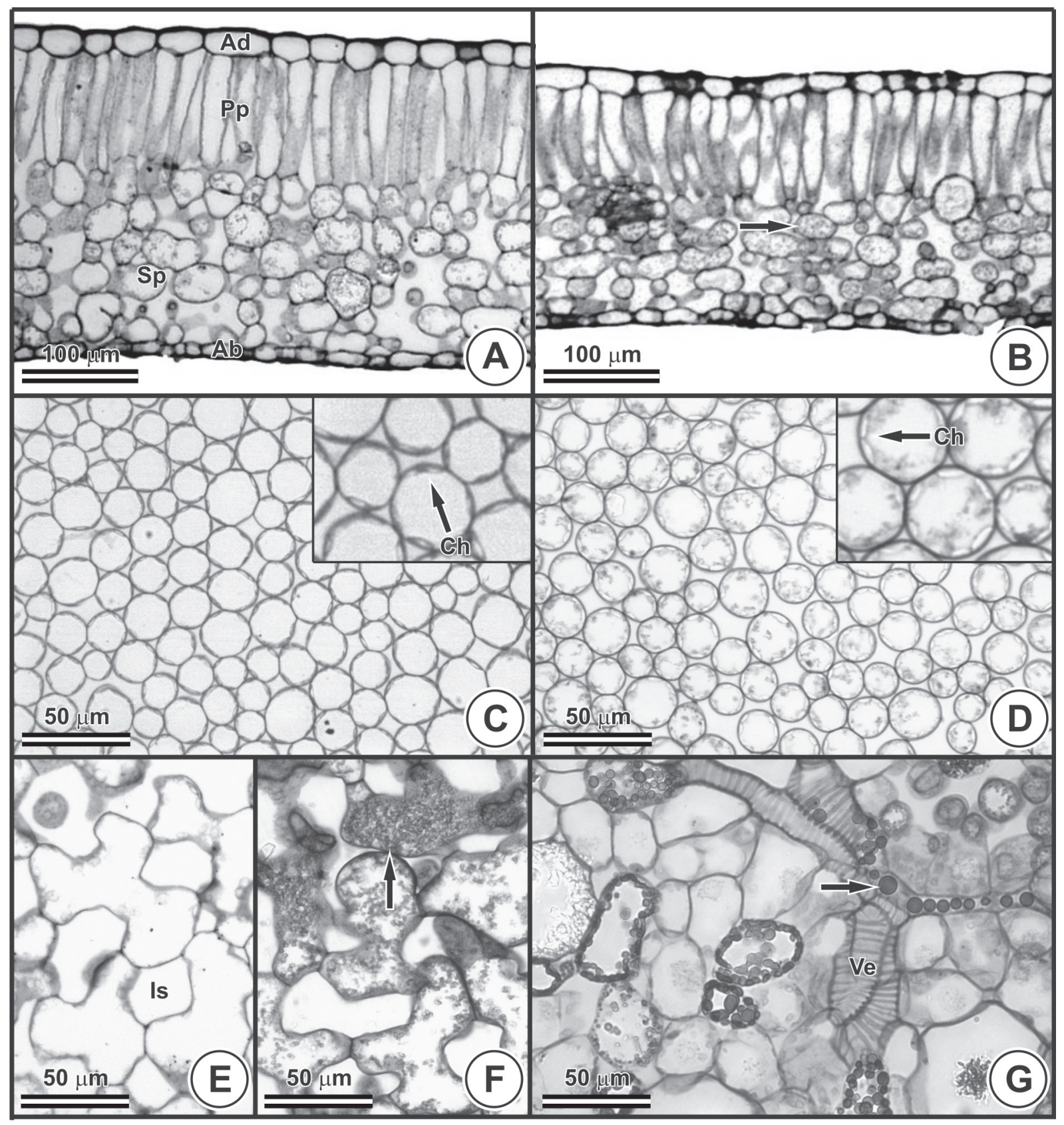

Fig. 7 - Leaf blade structure of $S$. dulcis (light microscopy of transverse (A and B) and paradermal (C-G) sections). (A, C and E) Control treatment. (B, D, F-G) Fluoride $\left(20 \mathrm{mg} \mathrm{L}^{-1}\right)$. (A) Leaflet mid-region. (B) Reduction of the limb thickness and the accumulation of granules (arrow) green stained by toluidine blue. (C and D) Cells from the palisade parenchyma with peripheral chloroplasts. (E) Armed cells of spongy parenchyma. (F and G) Granules (F) and droplets (G) green stained by toluidine blue in spongy parenchyma (F) and in the boundaries of the ending veinlets $(\mathbf{G})$ at the interface between the palisade and spongy parenchyma. Abbreviations: Ad: adaxial epidermis; Ab: abaxial epidermis; Ch: chloroplast; Ev: vessel element; Is: intercellular space; Pp: palisade parenchyma; Sp: spongy parenchyma. 
TABLE II

Mean values of the structural parameters of $\boldsymbol{S}$. dulcis plants exposed

to fluoride concentrations $\left(\mathrm{mg} \mathrm{L}^{-1}\right)$ during four consecutive days.

Means followed by the same letter in the line do not differ by the Tukey test at $5 \%$ probability. Each value represents the mean of five repetitions. Abbreviations: Ad: adaxial epidermis; Ab: abaxial epidermis;

Li: limb; Is: intercellular space; Pp: palisade parenchyma; Sp: spongy parenchyma.

\begin{tabular}{cccccc}
\hline$\mu \mathrm{m} / \mathrm{mg} \mathrm{L}^{-1}$ & $\mathbf{0}$ & $\mathbf{5}$ & $\mathbf{1 0}$ & $\mathbf{1 5}$ & $\mathbf{2 0}$ \\
\hline $\mathbf{A d}$ & $26.24 \pm 1.77 \mathrm{a}$ & $25.85 \pm 0.68 \mathrm{a}$ & $23.56 \pm 1.39 \mathrm{ab}$ & $22.47 \pm 2.06 \mathrm{~b}$ & $27.72 \pm 1.34 \mathrm{ab}$ \\
\hline $\mathbf{P p}$ & $94.58 \pm 3.20 \mathrm{a}$ & $80.03 \pm 1.76 \mathrm{~b}$ & $81.56 \pm 2.11 \mathrm{~b}$ & $83.45 \pm 7.49 \mathrm{~b}$ & $80.33 \pm 6.68 \mathrm{~b}$ \\
\hline $\mathbf{S p}$ & $135.79 \pm 2.11 \mathrm{a}$ & $116.63 \pm 0.72 \mathrm{c}$ & $125.3 \pm 2.83 \mathrm{~b}$ & $111.9 \pm 3.32 \mathrm{~b}$ & $115.32 \pm 4.06 \mathrm{~b}$ \\
\hline $\mathbf{A b}$ & $135.79 \pm 2.11 \mathrm{a}$ & $13.51 \pm 0.96 \mathrm{a}$ & $13.2 \pm 0.78 \mathrm{a}$ & $13.64 \pm 0.89 \mathrm{a}$ & $14.32 \pm 0.71 \mathrm{a}$ \\
\hline $\mathbf{L i}$ & $270.93 \pm 5.15 \mathrm{a}$ & $263.02 \pm 1.45 \mathrm{bc}$ & $243.61 \pm 2.48 \mathrm{~b}$ & $231.45 \pm 12.02 \mathrm{c}$ & $234.71 \pm 4.99 \mathrm{bc}$ \\
\hline $\mathbf{I s}$ & $18.73 \pm 0.63 \mathrm{~b}$ & $19.66 \pm 0.70 \mathrm{~b}$ & $22.97 \pm 0.75 \mathrm{a}$ & $22.97 \pm 0.75 \mathrm{a}$ & $23.43 \pm 0.66 \mathrm{a}$ \\
\hline
\end{tabular}

\section{DISCUSSION}

According to the literature, the symptoms of the exposure to fluoride are described as marginal necrosis and apical necrosis. In the majority of studies, a more accurate description of the differences in color in the necrosis is not presented (Silva et al. 2000, Chaves et al. 2002, Oliva and Figueiredo 2005).

In the present work, the brownish color observed in the necrosis likely indicates the oxidation of phenolic compounds that accumulated in response to the high concentration of fluoride in regions where the drops of the fog settled. This is consistent with the observations of Pita-Barbosa et al. (2009) in leaves of Brachiaria brizantha and B. decumbens that were exposed to fluoride. In leaves of Salvinia auriculata, Peixoto et al. (2005) highlighted the round shape and dark brown color of the necroses caused by fluoride. Fornasiero (2001) described the leaf necroses in plants of Hypericum perforatum in response to fluoride as red-brownish, indicating possible differences among plant species.

$S$. dulcis plants reacted rapidly to the pollutant, corroborating the Silva et al. (2000) report, which discovered the high sensitivity of this species to fluoride. Silva et al. (2000) also observed necroses $24 \mathrm{~h}$ after the first exposure to the simulated rain containing $30 \mathrm{mg} \mathrm{L}^{-1}$ of fluoride without the appearance of chlorosis. In Hypericum perforatum plants exposed to the pollutant (Fornasiero 2001), chloroses preceded the necrosis of the leaf tissue, a finding also reported by Silva et al. (2000) in Gallesia gorazema. The high sensitivity of $S$. dulcis to fluoride leads to rapid tissue death and does not allow enough time for the formation of chlorosis. Nevertheless, the rapid outbreak of necrosis may be related to the exposure of the plants to high pollutant concentrations (Weinstein and Davison 2003). The symptoms observed in $S$. dulcis plants exposed to the fluoride fog in the present experiment were identical to those observed in previous experiments using a fluoride rain simulation (Sant'Anna-Santos and Azevedo 2007). This highlights the reliability of the use of the symptomatology in the diagnosis of the stress caused by the pollutant.

In S. dulcis the data measuring the accumulation of the pollutant suggest a higher capacity of accumulation by the leaves under expansion, as the dry matter from the apical portion showed a higher content of fluoride than the matter from the basal portion. The amount of fluoride accumulated and the degree of injury in the tissues may vary with the age of the leaf (Silva et al. 2000).

In $S$. dulcis, the leaves from the apical portion of the plant accumulated more fluoride than the basal leaves and showed a higher percentage of 
necrosed leaf areas. This was also observed in Magnolia ovata plants exposed to the pollutant (Sant'AnnaSantos et al. 2007). In some plant species there is a correlation between the degree of injury and the high rates of accumulation of the pollutant (Klumpp et al. 1995, Silva et al. 2000, Fornasiero 2001).

Fluoride, provided to a plant through simulated rain or fog, reaches the internal part of a leaf mainly throughout the cuticle. The fluoride may then be absorbed by the cells of the mesophyll, reaching the symplast, or the fluoride may be dragged by the transpiration stream to the ending veinlets where it is accumulated (Oliva and Figueiredo 2005). The fluoride distribution pattern in most grass species suggests that it is accumulated in tissues with high metabolic activity (Oliva and Figueiredo 2005). The entrance of the anion throughout the apoplast in the young tissues of plants is facilitated by the small amount of cutin and epicuticular waxes in the epidermal cells, and by the high amount of pectins (Kannan 1986) in comparison to expanded leaves.

Because attributing a symptom to a specific stress factor is difficult, the symptomatology requires other parameters, such as microscopic analysis, to ensure a precise diagnosis (Vollenweider et al. 2003, Reig-Arminaña et al. 2004). In this work the treatment with fluoride caused alterations in both surfaces of the epidermis at all assessed concentrations (5, 10, 15 and $20 \mathrm{mg} \mathrm{L}^{-1}$ ). The samples were taken from leaves without any apparent fluoride injury. The micromorphological alterations observed in the leaf blades of $S$. dulcis are most likely related to fluoride-induced changes in the cuticle and epicuticular wax structure, which would facilitate the entrance of fluoride into the epidermis and would allow, secondarily, the invasion of pathogens (Heredia et al. 1998). Similar results for this species were observed by Sant'Anna-Santos et al. (2006) in response to acid rain.

There are few reports on the effects of fluoride on leaf micromorphology (Chaves et al. 2002, Sant'Anna-Santos and Azevedo 2007, Sant'Anna-
Santos et al. 2007), and little attention is given to this parameter as a prognostic biomarker. The presence of damage in samples from leaflets without apparent fluoride injury indicates the usefulness of micromorphology for field biomonitoring studies and as a biomarker for the presence of the pollutant in the atmosphere.

The green color given by toluidine blue indicates the phenolic nature of the granules and droplets observed through the light microscope, according to Briggs et al. (2005). According to Oliva and Figueiredo (2005), fluoride is accumulated in the boundaries of the ending veinlets, which explains the accumulation of phenolic compounds in this region. The accumulation of phenols has been interpreted as a defence mechanism of plants (Vaughn and Duke 1984, Changlian et al. 2006) and has been reported in other plant species exposed to fluoride (Chaves et al. 2002, Sant'AnnaSantos et al. 2007). The reduction in the thickness of leaflets that did not show symptoms of exposure to the pollutant reflects the alterations in leaf relief observed through scanning electron microscopy. Therefore, the use of light microscopy, among other techniques, is necessary for optimizing the characterization of fluoride phytotoxicity.

Most concentrations of fluoride used in the fog experiments caused a rapid development of necroses and induced leaf abscission, with the exception of the $5 \mathrm{mg} \mathrm{L}^{-1}$ one. Thus, this concentration can be used in further experiments to assess the chlorosis that precedes tissue necroses, as it would induce injuries more slowly. The symptoms observed in $S$. dulcis in response to fluoride are not plant-specific. $S$. dulcis shows color injuries, the beginning of necrosis at the basal portion of the leaflet and the highest percentage of the leaf area damaged by necrosis at the apical part of the plant. Therefore, in active biomonitoring studies, the assessment of specific patterns in the precise diagnosis of injuries caused by fluoride is strongly advised. The alterations in the structure and micromorphology 
were evident in the leaflet samples without any apparent fluoride injury, demonstrating that these tools are potentially useful in the prognosis of fluoride injury. The use of such techniques in future experiments, in addition to physiological and ultrastructural analyses, will be essential for elucidating the phytoxicity caused by pollutants.

\section{ACKNOWLEDGMENTS}

The authors thank Coordenação de Aperfeiçoamento de Pessoal de Nível Superior (CAPES) for a scholarship, the Nursery of Parque Estadual do Rio Doce-MG (NPERD) for supplying the plants and the Núcleo de Microscopia e Microanálise (Universidade Federal de Viçosa-UFV) for helping with the elaboration of the electron microscopy part of this work.

\section{RESUMO}

O objetivo deste estudo foi determinar os sintomas e danos microscópicos causadas pelo flúor em Spondias dulcis, espécie sensível a essa substância. As plantas foram expostas a nevoeiros simulados com flúor $(0,5,10$, 15 e $20 \mathrm{mg} \mathrm{L}^{-1}$ ) por 20 minutos diários, durante quatro dias consecutivos. Amostras de folíolos sem qualquer lesão aparente ao flúor foram coletadas para análise microscópica. Mensurou-se a percentagem de área foliar necrosada e o teor do poluente na matéria seca das porções basal e apical da planta. As necroses surgiram 24 horas após a primeira simulação e tiveram início, principalmente, a partir da base dos folíolos. As necroses foram mais severas na porção apical das plantas, região com maior acúmulo de flúor. O dano na superfície dos folíolos foi caracterizado como plasmólise, erosão das ceras epicuticulares e ruptura da epiderme. Estruturalmente, observou-se considerável acúmulo de grânulos e gotas coradas de verde pelo azul de toluidina no parênquima lacunoso e nas proximidades das terminações xilemáticas. Houve redução da espessura do limbo devido a plasmólise no mesofilo, havendo aparente correlação com os danos observados na superfície. Os parâmetros observados em laboratório são promissores para estudos de biomonitoramento em campo.
Palavras-chave: Anatomia foliar, bioindicador, necrose, poluição, sintomatologia.

\section{REFERENCES}

BRIGGS CL, MORRIS EC AND ASHFORD AE. 2005. Investigations into seed dormancy in Grevillea linearifolia, G. buxifolia and $G$. sericea: Anatomy and histochemistry of the seed coat. Annals Bot 96: 965-980.

Changlian P, Zhifang L, Guizhu L and Shaowei C. 2006. The antiphotooxidation of anthocyanins-rich leaves of a purple rice cultivar. Sci China C Life Sci 49: 543-551.

Chaves Alf, Silva EAM, AzEvedo AA, CANO MAO AND MATSUOKA K. 2002. Ação do flúor dissolvido em chuva simulada sobre a estrutura foliar de Panicum maximum Jacq. (colonião) e Chloris gayana Kunth. (capim-Rhodes) - Poaceae. Acta Bot Bras 16: 395-406.

Divan Junior AM, Oliva MA AND Ferreira FA. 2008. Dispersal pattern of airborne emissions from an aluminium smelter in Ouro Preto, Brazil, as expressed by foliar fluoride accumulation in eight plant species. Ecol Indicators 8: 454-461.

DIVAN JUNIOR AM, OLIVA MA, MARTINEZ CA AND CAMBRAIA J. 2007. Effects of fluoride emissions on two tropical grasses: Chloris gayana and Panicum maximum cv. Colonião. Ecotoxicol Environ Saf 67: 247-253.

Domingos M, KlumpP A, Rinaldi MCS, Modesto I, KLumpP G AND DelitTI WBC. 2003. Combined effects of air and soil pollution by fluoride emissions on Tibouchina pulchra Cogn., at Cubatão, SE Brazil, and their relations with aluminum. Plant Soil 249: 297-308.

ELLENBERG H. 1991. Bioindicator and biological monitoring. In: Biological monitoring. Signal from the environment. Gate/GTZ, Braunschweig, p. 13-74.

EUCLYDES RF. 1983. Sistema de Análises Estatísticas e Genéticas da UFV (SAEG) - Manual. CPD/UFV, Divisão de Pesquisas e Desenvolvimento. Viçosa, Minas Gerais.

EVANS LS, GMUR NF AND COSTA F. 1977. Leaf surface and histological perturbations of leaves of Phaseolus vulgaris and Helianthus annuus after exposure to simulated acid rain. Am J Bot 64: 903-913.

ForNASIERO RB. 2001. Phytotoxic effects of fluorides. Plan Sci 161: 979-985.

Garcia-CIUdAD A, Garcia-Criado B AND PONTÓN-SAN EMETERIO C. 1985. Determination of fluoride in plant samples by a potentiometric method and near-infrared reflectance spectroscopy. Comm Soil Sci Plant Anal 16: 1107-1122.

GÜNTHARDT-GOERG MS AND VOLLENWEIDER P. 2007. Linking stress with macroscopic and microscopic leaf response in trees: New diagnostic perspectives. Environ Pollut 147: 467-488.

Heredia A, Casado CG, Laguna L, Reina JJ, Serrano JM AND DOMÍNGUEZ E. 1998. La cuticula vegetal: estructura y funciones. Ecologia 2: 293-305.

HoAGLAND DR AND ARNON DI. 1950. The water-culture method for growing plants without soil. Calif Agric Exp Sta Circ 347: 1-32. 
KANNAN S. 1986. Physiology of foliar uptake of inorganic nutrients. Proc Indian Acad Sci 96: 457-70.

KARNOVSKY MJ. 1965. A formaldehyde-glutaraldehyde fixative of high osmolarity for use in electron microscopy. J Cell Biol 27: 137A.

Klumpr A, Domingos M, De Moraes RM and KlumpP G. 1998. Effects of complex air pollution on tree species of the Atlantic Rain Forest near Cubatão, Brazil. Chemosphere 36: 989-994.

KlumpP A, Domingos M AND KlumpP G. 1996a. Assessment of the vegetation risk by fluoride emissions from fertiliser industries at Cubatão, Brazil. Sci Total Environ 192: 219-228.

Klumpr A, Klumpr G, DOMINGOS M AND GUdERIAN R. 1995. Hemerocallis as bioindicator of fluoride pollution in tropical countries. Environ Monit Asses 35: 27-42.

Klumpr A, Klumpr G, Domingos M AND Silva MD. 1996b. Fluoride impact on native tree species of the atlantic forest near Cubatão, Brazil. Water Air Soil Pollut 87: 57-71.

LARSEN S AND WIDDOWSON AE. 1971. Soil fluorine. J Soil Sci 22: 210-221.

LORENZI H, SOUZA HM, TORRES MAV AND BACHER LB. 2003. Árvores exóticas no Brasil: madereiras, ornamentais e aromáticas. Nova Odessa: Instituto Plantarum de Estudos da Flora Ltda, 382 p.

MunNÉ-Bosch S AND Alegre L. 2004. Die and let live: leaf senescence contributes to plant survival under drought stress. Funct Plant Biol 31: 203-216.

O'BRIEN PP AND MCCUlly ME. 1981. The study of plants structure principles and select methods. Termarcarphi Pty. Ltda, Melbourne-Australia, $45 \mathrm{p}$.

Oliva MA AND FIGUEIREDO JG. 2005. Gramíneas bioindicadoras de flúor em regiões tropicais. Rev Bras Bot 28: 389-397.

Peixoto PHP, PIMENTA DS AND ANTUNES F. 2005. Efeitos do flúor em folhas de plantas aquáticas de Salvinia auriculata. Pesqu Agropecu Bras 40: 727-734.

Pita-Barbosa A, SAnt'Anna-Santos BF, Silva KLF, AZEVEDO AA AND RochA DI. 2009. Efeitos fitotóxicos do fluoreto na morfoanatomia foliar de Brachiaria brizantha (Hochst. ex A. Rich.) Stapf e Brachiaria decumbens Stapf (Poaceae). Acta Bot Bras 23: 1027-1033.

Reig-Arminaña J, Calatayud V, Cervero J, Garcia-Breijo FJ, IBARS A AND SANZ MJ. 2004. Effects of ozone on the foliar histology of the mastic plant (Pistacia lentiscus L.) Environ Pollut 132: 321-331.
RUTHSATZ B AND WEY H. 1991. Concept for a biological monitoring study. In: Biological monitoring. Signal from the environment. Gate/GTZ ed., Braunschweig, p. 75-128.

SANT'ANNA-SANTOS BF AND AZEVEDO AA. 2007. Aspectos morfoanatômicos da fitotoxidez do flúor em duas espécies arbóreas tropicais. Rev Bras Biocienc 5: 48-50.

Sant'AnNa-Santos BF, DuQue-Brasil R, AZEVEdo AA, SILVEIRA AS, ARAÚJo JM AND AGUIAR R. 2007. Utilização de parâmetros morfoanatômicos na análise da fitotoxidez do flúor em folhas de Magnolia ovata (A. St.-Hil.) Spreng. (Magnoliaceae). Rev Árvore 31: 761-771.

SANT'AnNA-Santos BF, Silva LC, AZEVEdo AA, ARAúJo JM, Alves EF, Silva EAM AND Aguiar R. 2006. Effects of simulated acid rain on the foliar micromorphology and anatomy of tree tropical species. Environ Exp Bot 58: 158-168.

Silva LC, AzeVEdo AA, Silva EAM AND Oliva MA. 2000. Flúor em chuva simulada: sintomatologia e efeitos sobre a estrutura foliar e o crescimento de plantas arbóreas. Rev Bras Bot 23: 385-393.

Smith FA AND Hodge H. 1979. Airborne Fluorides and Man: Part I. CRC Critical Review of Environ. Control 8: 293372.

Souza FX, Sousa FHL AND Melo FIO. 1998. Aspectos morfológicos de endocarpos de cajarana (Spondias cytherea sonn. - Anacardiaceae). Rev Bras Sementes 20: 141-146.

VAUGHN K AND DUKE SO. 1984. Function of polyphenol oxidase in higher plants. Phys Plantarum 60: 106-112.

VDI. 1982. Richtlinie 3792. Messen der Immissions-Wirkdosis von gas-und staubförmigem Fluorid in Pflanzen mit dem Verfahren der standardisierten Graskultur. Blatt 2. VDIHandbuch Reinhaltung der Luft. Verein Deutscher Ingenieure, Düsseldorf, p. 1-6.

VOLLENWEIDER P, OtTIGER M AND GÜNTHARDT-GOERG MS. 2003. Validation of leaf ozone symptoms in natural vegetation using microscopical methods. Environ Pollut 124: $101-118$

WEINSTEIN LH AND DAVISON AW. 2003. Native plant species suitable as bioindicators and biomonitors for airborne fluoride. Environ Pollut 125: 3-11. 